Article

\title{
Urban Quality of Life: Spatial Modeling and Indexing in Athens Metropolitan Area, Greece
}

\author{
Antigoni Faka*(D), Kleomenis Kalogeropoulos (D), Thomas Maloutas (D) and Christos Chalkias \\ Department of Geography, Harokopio University of Athens, GR-176 76 Kallithea, Greece; \\ kalogeropoulos@hua.gr (K.K.); maloutas@hua.gr (T.M.); xalkias@hua.gr (C.C.) \\ * Correspondence: afaka@hua.gr; Tel.: +30-210-9549347
}

check for updates

Citation: Faka, A.; Kalogeropoulos, K.; Maloutas, T.; Chalkias, C. Urban Quality of Life: Spatial Modeling and Indexing in Athens Metropolitan Area, Greece. ISPRS Int. J. Geo-Inf. 2021, 10, 347. https://doi.org/ 10.3390 /ijgi10050347

Academic Editor: Wolfgang Kainz

Received: 31 March 2021

Accepted: 15 May 2021

Published: 18 May 2021

Publisher's Note: MDPI stays neutral with regard to jurisdictional claims in published maps and institutional affiliations.

Copyright: (c) 2021 by the authors. Licensee MDPI, Basel, Switzerland. This article is an open access article distributed under the terms and conditions of the Creative Commons Attribution (CC BY) license (https:// creativecommons.org/licenses/by/ $4.0 /)$.

\begin{abstract}
The purpose of this study is to assess and visualize the Quality of Life provided by urban space as a place of residence. The proposed methodology, after its theoretical documentation, is implemented in Athens Metropolitan Area, Greece. For the evaluation of Urban Quality of Life, a complex index is constructed by using multicriteria analysis. For this purpose, Quality of Life controlling factors such as built space, natural, socioeconomic, and cultural environment, infrastructure and services, and the quality of housing were analyzed within a GIS environment. The mapping of this index led to the identification of areas with different levels of Quality of Life. The results of the research can lead to more effective decision making regarding the planning of targeted actions and the distribution of financial resources to improve the Quality of Life of the residents in urban areas.
\end{abstract}

Keywords: quality of life; GIS; mapping; Athens; Greece

\section{Introduction}

Quality of life (QoL) has been of particular concern to researchers in the social sciences, humanities, and environmental sciences, as well as health sciences and psychology. Accordingly, a large number of definitions for QoL have been proposed in the international literature [1]. Thus, QoL is a complex concept that is difficult to define in one dimension [2-4], although the common perception is that QoL has mainly health properties [5].

The World Health Organization Quality of Life (WHOQOL) defined QoL as "individuals perceptions of their position in life in the context of the culture and value systems in which they live and in relation to their goals, expectations, standards and concerns". This is a broad approach integrating physical health, psychological state, level of independence, social relationships, personal beliefs, and their relationships to salient features of the environment [6]. QoL assessment remains in the center of research interest, regarding the conditions of the natural and living environment, the needs of the individuals in a society, as well as the importance of these needs constantly changing over time [7].

After the end of World War II, QoL was mainly identified with the concept of living standards as well as the acquisition of consumer goods and property. Gradually, the research community began to examine the by QoL taking into account parameters related to health, education, and the natural environment. In the 2000s, efforts were made toward a multilevel approach of QoL. Typically, the European Union (EU) has designed and carried out a series of surveys studying QoL in terms of economy, employment, health, education, services, living and housing conditions, security, environmental quality, culture, family, social life, etc. [8-13].

In recent decades, a lot of research has been conducted to evaluate QoL, both individually and geographically, and many methodologies have been proposed for these analyses [14,15]. As the mapping of the QoL can highlight effectively its spatial distribution [16,17], QoL maps support decision making for targeted actions toward the improvement of QoL within the area under investigation. 
Many studies have reported the spatial dimension of QoL, underlying the importance of a "good place" as a place where people can experience a good life $[7,18,19]$. The spatial aspect of QoL has been examined in terms of (a) health-influencing factors [20-26], (b) house choice $[27,28]$, (c) accessibility to transportation infrastructures [29,30], (d) availability of sustainable public space, (e) environmental conditions and climate change [31], and (e) urban inequalities [7,32].

The spatial dimension of QoL also receives increasing interest from governments and local authorities, who face the challenge of making decisions for the improvement of QoL for their citizens. Global and European organizations have conducted several surveys for the assessment and mapping of QoL at both national and local level [11,12,33,34]. However, there is no single and commonly accepted methodology for this evaluation. Eurostat has end up with the following nine dimensions of QoL: Material living conditions (income, consumption, and material conditions), Productive or main activity, Health, Education, Leisure and social interactions, Economic security and physical safety, Governance and basic rights, Natural and living environment, and Overall experience of life. These dimensions are going beyond Gross Domestic Product toward sustainable QoL [35].

By taking into account the multidimensional nature of QoL, its evaluation should be based on the clarification of a set of conceptual and methodological issues. A key factor in the evaluation of QoL is the degree of specialization, which concerns the degree of specificity that QoL is approached in research [36]. The general level is related to the evaluation of QoL as a whole, while the specific level concerns the evaluation of certain or even a specific area of QoL [37]. Therefore, the degree of specialization determines respectively the areas under the study of QoL. Assessing the QoL that provides an area as a place of residence, the areas that compose the living environment are explored, such as the built space, the natural environment, the socioeconomic environment, the quality of housing, and housing conditions, infrastructure and services, as well as the cultural environment [7].

The evaluation of QoL is based on the evaluation of its components by using relevant variables or even by creating complex indicators [38]. The selection of the variables for the evaluation of the QoL is another critical factor. The type of variables is related to whether the assessment of the living environment in an area is carried out using inventory data, geographical data, etc., or is based on the recruitment of residents. However, many studies use both these two types of variables, arguing that residents' perceptions in combination with environmental conditions contribute to the integrated approach of the QoL [36,39].

The geographical scale of analysis is an important factor for the study of QoL [36,40]. QoL can be assessed at various levels, from local to national. For example, the assessment of QoL at the national or regional level could obscure local issues that degrade QoL and can provide important information and suggest areas for detailed research. However, policy decisions often require detailed analysis. Moreover, the geographical scale often defines the variables that will be used for the analysis. For example, the value of the Gross Domestic Product index is used mainly at the national level.

The QoL has been extensively explored in urban areas. Cities play an important role in the economic and regional development of a country as they gather a large part of the population, are centers of innovation and technology, offer jobs and higher education services, etc. At the same time, urban areas are facing problems such as social inequalities, environmental degradation, crime, etc. [13]. The assessment of the quality of "urban" life has increased interest from the global research community in recent years [15,4147] on issues related to crime, poverty, socioeconomic and environmental degradation, etc. [13,48-50]. Here, although the analysis is focused on urban areas, we use the general term QoL.

In this study, we propose a GIS-based spatial multicriteria analysis for the assessment of QoL. The main aim was to develop a model toward QoL indexing and mapping. The underlying hypothesis of this work is that QoL per municipality is subject to its socioeconomic and environmental properties. In addition, this work assumes that the proposed concept can be implemented with only minor changes in other areas by taking into consid- 
eration similar variables and indicators. The data processing is based on GIS technology, which allows the connection of statistical variables with spatial data, providing at the same time the proper spatial analysis and mapping functionality [51,52]. The proposed indicator for the assessment of QoL is formed by complex criteria related to the urban tissue, the natural socioeconomic and cultural environment, the quality of housing, and the proximity to infrastructures and services. The use of corresponding criteria has been proposed and implemented in similar analyses around the world [16,46,53-55]. Finally, the performance of the proposed GIS-based model was evaluated by empirical analysis in Athens Metropolitan Area (AMA), Greece.

\section{Study Area}

The city of Athens is located in Attica prefecture, in the central part of Greece (Figure 1). Athens is the capital and the largest city of Greece. The municipality of Athens (18 in Figure 1) has a population of 664,046 inhabitants (2011 Population Census) and extends over an area of almost $40 \mathrm{~km}^{2}$. AMA extends way beyond and covers an area of about $400 \mathrm{~km}^{2}$. According to Eurostat in 2004, AMA is the 7th largest Urban Zone (LUZ) in the European Union with more than 4,000,000 inhabitants [56].

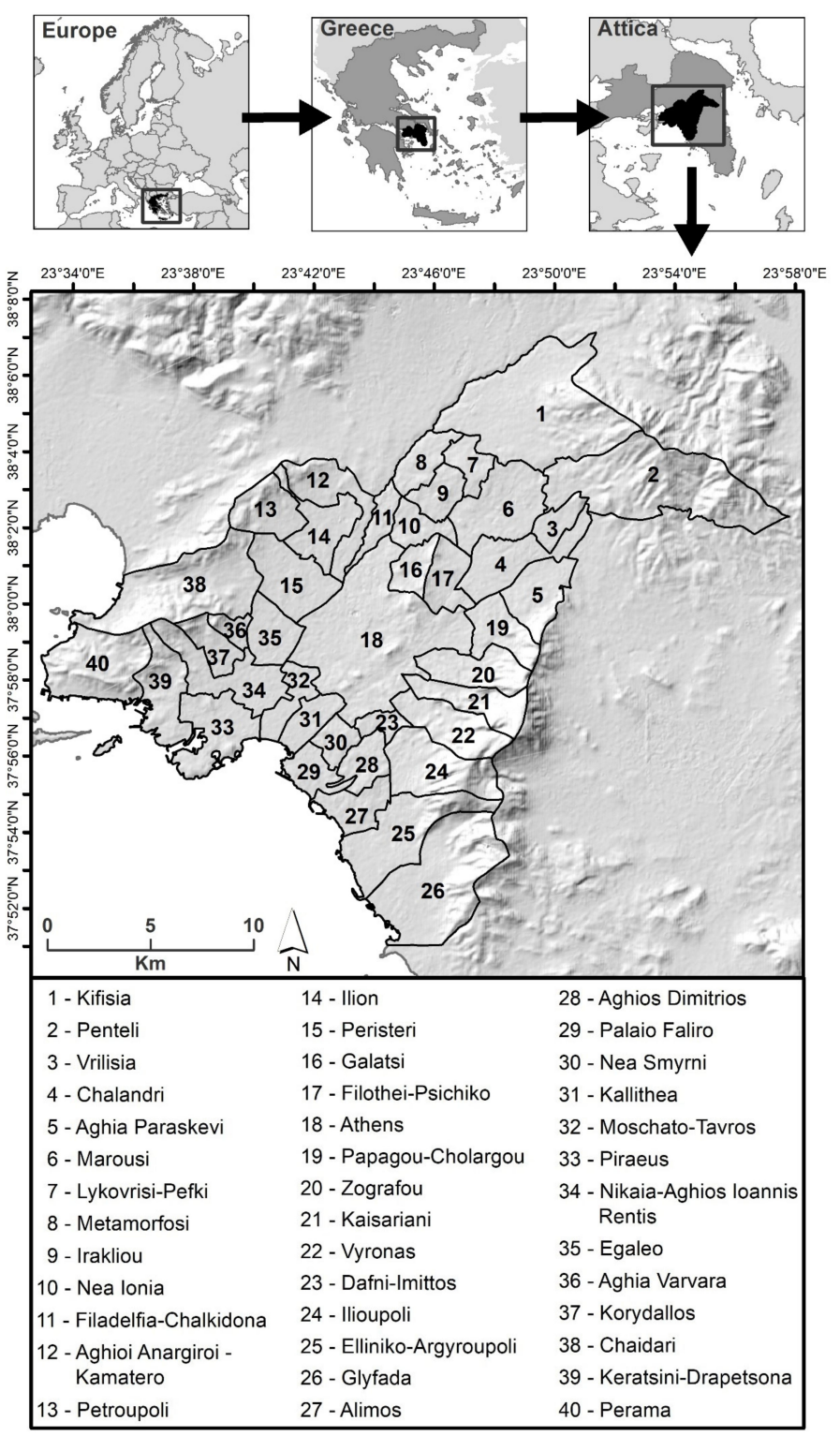

Figure 1. The study area of Athens Metropolitan Area, in Attica, Greece. 
In addition, according to QoL reports of the European Commission (EC), the satisfaction of Athens inhabitants with public spaces such as markets, squares, and pedestrian zones in AMA was 51\%, and the presence of foreigners is generally viewed as positive from $53 \%$ of the respondents. Furthermore, in AMA, the majority of respondents feel safe $(63 \%)$, are satisfied with green spaces $(56 \%)$ and with the place where they live $(76 \%)$, while $63 \%$ are not satisfied with the financial situation of their household, and the satisfaction with the personal job situation was $45 \%$ [12].

AMA is characterized by spatial heterogeneity, bounded by mountains and comprising of continuous built-up areas. Central municipalities of AMA are densely populated, whereas the urban tissue in the municipalities on the borders of the mountainous areas is less dense, including extended open spaces. The urban tissue characteristics of contemporary AMA are related to the uncontrolled increase in population and the mass construction of apartment buildings in the post-war period. Nowadays, AMA deals with significant socioeconomic inequalities and disparities in population composition and physical environment, as a result of the social and economic crisis, population mobility, and immigration [57].

\section{Materials and Methods}

Spatial modeling of QoL was based on GIS, using statistical and spatial data to assess QoL domains (Figure 2). Each domain was evaluated by a composite criterion and each criterion was estimated by a set of indicators.

\subsection{Criteria and Variables}

QoL was assessed by a composite index constructed from six criteria. Each criterion referred to a domain of QoL and was estimated by a set of indicators. Various domains and variables to evaluate QoL have been proposed, although some of them, including socioeconomic environment, proximity to public services and recreational facilities, housing conditions, and natural and built environment, recur in most studies. The criteria of the proposed index were based on these domains and composed of indicators that evaluate the specific domain of QoL (Figure 2).

The impact of the built and natural environment on both physical and mental health has been noticed in many studies $[13,58]$. QoL in cities may be positively affected by higher population density in terms of social coherence [59]. However, overall life satisfaction tends to be higher in less densely populated areas [60], as long as non-densely populated areas combined with open spaces provide better neighborhood QoL [61]. Based on this, population density and the percentage of open spaces were used to evaluate the built environment. In accordance with the fact that noise and air pollution are two major problems in urban environments with considerable negative effects on people's health [62], the criterion of the natural environment was assessed based on sources of noise and air pollution, using the mean distance to industrial units, the density of high-traffic roads and highways, as well as the percentage of green urban areas.

Socioeconomic status is directly linked to QoL [63]. Higher education affects the material living conditions of individuals, leading to higher earnings and employability [64]. According to the 3rd European QoL survey, low income and low educational attainment were associated with increased material deprivation [63] and difficulties in satisfying basic needs, which have a strong impact on QoL [65]. In this study, the socioeconomic environment was evaluated from variables related to unemployment, educational level (according to the International Standard Classification of Education (ISCED) [66]), as well as mean annual income.

The last criterion is related to recreational and cultural facilities. Attendance to culturerelated activities has positive effects on well-being and quality of life [71]. Furthermore, recreational and leisure facilities are strong predictors of QoL [72,73], as meeting places where social relationships can be formed and maintained [74,75]. In this study, indicators of proximity to recreational and cultural facilities were used to estimate this criterion. We as- 
sumed recreational parks, theaters, and cinemas as recreational facilities, and archaeological sites, museums, and libraries as cultural facilities.

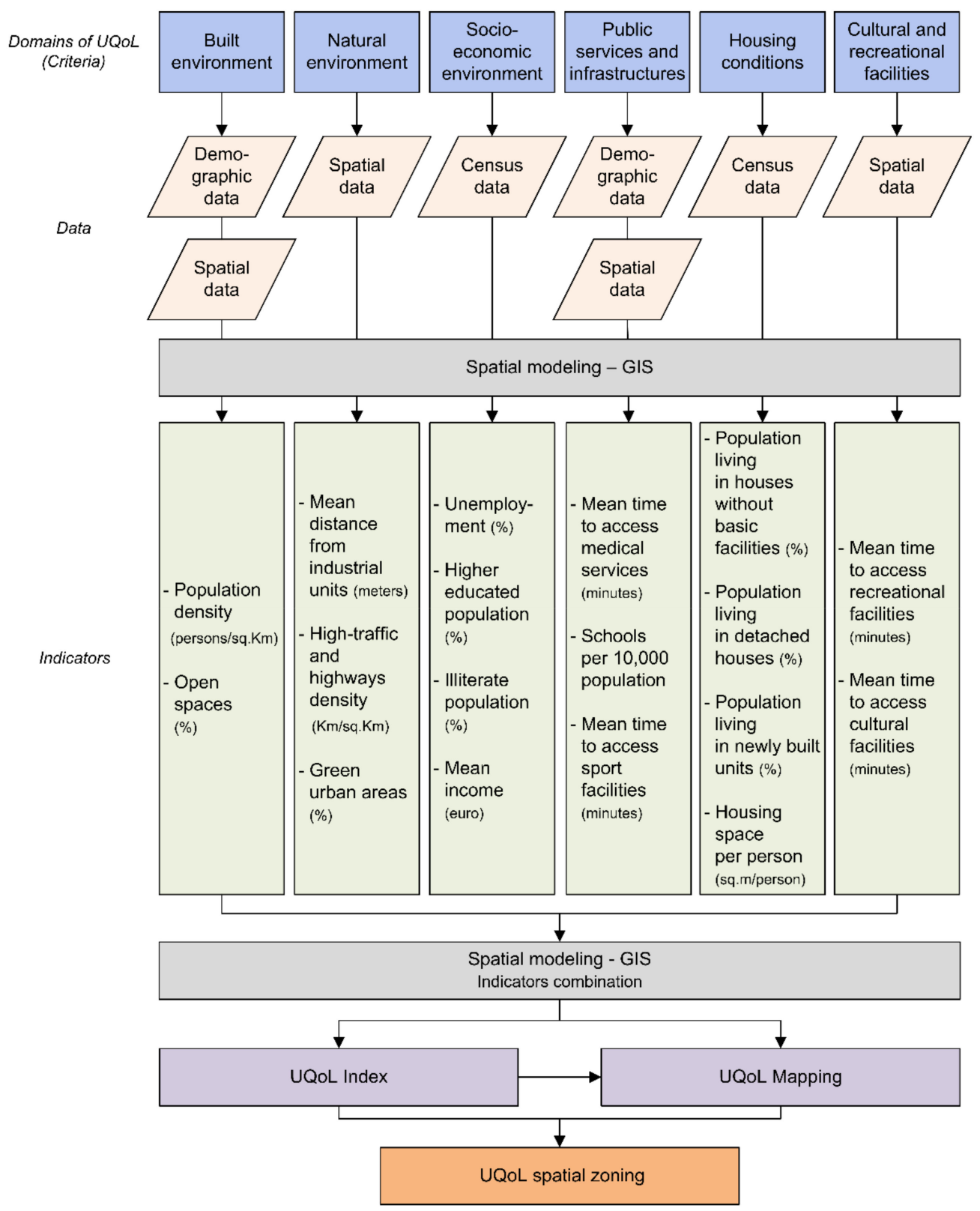

Figure 2. Workflow of evaluating and mapping UQoL.

The access to public services and facilities and its impact on QoL has been noticed in many studies [11,67-69]. Access to essential facilities and public services impacts health, economic prosperity, sense of security, and the general well-being of individuals [70]. The criterion of public services and facilities was evaluated by indicators of accessibility, in terms of proximity (minutes to access) to hospitals and sports facilities, and the index of schools per 10,000 population. Proximity to hospitals and sports facilities was produced through GIS spatial analysis functions using the corresponding spatial layers of points of interest and the road network.

The housing environment affects an individual's everyday life. Housing conditions usually refer to the quality and amenities of the building as well as to the sufficient housing space $[11,15,16]$. In this study, the criterion of housing conditions was evaluated by indicators related to the population living in houses without basic facilities (heating, WC, 
bathroom, kitchen), in detached houses, in newly built units (during the last five years), and housing space $\left(\mathrm{m}^{2}\right)$ per person.

Table 1 presents the properties of the data described above.

Table 1. Datasets and sources per indicator.

\begin{tabular}{|c|c|c|}
\hline Indicators & Dataset, Year & Source \\
\hline \multirow{2}{*}{ Population density } & \multirow{2}{*}{$\begin{array}{l}\text { Population, } 2011 \\
\text { Spatial layer (polygon) of } \\
\text { municipalities, } 2011\end{array}$} & Hellenic Statistical Authority \\
\hline & & Hellenic Statistical Authority \\
\hline \multirow[t]{2}{*}{$\%$ Open spaces } & \multirow{2}{*}{$\begin{array}{l}\text { Spatial layer (polygon) of open spaces, } \\
\text { including cultivations, forests, green } \\
\text { urban areas, herbaceous vegetation, } \\
\text { pastures, crops, water, land without } \\
\text { current use, } 2012 \\
\text { Spatial layer (polygon) of } \\
\text { municipalities, } 2011\end{array}$} & $\begin{array}{l}\text { Urban Atlas-European } \\
\text { Environment Agency }\end{array}$ \\
\hline & & Hellenic Statistical Authority \\
\hline \multirow{2}{*}{$\begin{array}{l}\text { Mean distance to } \\
\text { industrial units }\end{array}$} & $\begin{array}{l}\text { Spatial layer (points) of industrial units, } \\
2020\end{array}$ & Google Maps \\
\hline & $\begin{array}{l}\text { Spatial layer (polygon) of } \\
\text { municipalities, } 2011\end{array}$ & Hellenic Statistical Authority \\
\hline Indicators & Dataset, Year & Source \\
\hline \multirow[t]{2}{*}{$\begin{array}{l}\text { Density of } \\
\text { high-traffic roads } \\
\text { and highways }\end{array}$} & \multirow{2}{*}{$\begin{array}{l}\text { Spatial layer (polyline) of high-traffic } \\
\text { roads and highways, including } \\
\text { motorways, trunks, primary, secondary } \\
\text { and tertiary road network, } 2020 \\
\text { Spatial layer (polygon) of } \\
\text { municipalities, } 2011\end{array}$} & OpenStreetMap.org \\
\hline & & Hellenic Statistical Authority \\
\hline \multirow{2}{*}{$\%$ Green urban areas } & \multirow{2}{*}{$\begin{array}{l}\text { Spatial layer (polygon) of green urban } \\
\text { areas, } 2012 \\
\text { Spatial layer (polygon) of } \\
\text { municipalities, } 2011\end{array}$} & $\begin{array}{l}\text { Urban Atlas-European } \\
\text { Environment Agency }\end{array}$ \\
\hline & & Hellenic Statistical Authority \\
\hline \multirow{2}{*}{ \% Unemployment } & Unemployed population, 2011 & Hellenic Statistical Authority \\
\hline & Economically active population, 2011 & Hellenic Statistical Authority \\
\hline \multirow{2}{*}{$\begin{array}{l}\% \text { Higher educated } \\
\text { population }\end{array}$} & $\begin{array}{l}\text { Population of ISCED level 8, 7, 6, and 5, } \\
2011\end{array}$ & Hellenic Statistical Authority \\
\hline & $\begin{array}{l}\text { Total population (population born after } \\
2005 \text { was excluded), } 2011\end{array}$ & Hellenic Statistical Authority \\
\hline \multirow{2}{*}{$\begin{array}{l}\% \text { Illiterate } \\
\text { population }\end{array}$} & \multirow{2}{*}{$\begin{array}{l}\text { Population of ISCED level 0, } 2011 \\
\text { Total population (population born after } \\
2005 \text { was excluded), } 2011\end{array}$} & Hellenic Statistical Authority \\
\hline & & Hellenic Statistical Authority \\
\hline Mean income & Mean income in euro, 2016 & $\begin{array}{l}\text { General Secretariat for } \\
\text { Information Systems (GSIS) of } \\
\text { the Greek Ministry of } \\
\text { Economy and Finance }\end{array}$ \\
\hline \multirow{3}{*}{$\begin{array}{l}\text { Proximity to medical } \\
\text { services/hospitals }\end{array}$} & $\begin{array}{l}\text { Spatial layer (points) of public } \\
\text { hospitals, } 2020\end{array}$ & Google Maps \\
\hline & $\begin{array}{l}\text { Spatial layer (polyline) of road network, } \\
2020\end{array}$ & OpenStreetMap.org \\
\hline & $\begin{array}{l}\text { Spatial layer (polygon) of } \\
\text { municipalities, } 2011\end{array}$ & Hellenic Statistical Authority \\
\hline \multirow{3}{*}{$\begin{array}{l}\text { Schools per } 10,000 \\
\text { population }\end{array}$} & $\begin{array}{l}\text { Spatial layer (points) of public primary } \\
\text { schools, } 2019\end{array}$ & $\begin{array}{l}\text { Greek Ministry of Education } \\
\text { and Religious Affairs }\end{array}$ \\
\hline & $\begin{array}{l}\text { Spatial layer (points) of public } \\
\text { secondary schools, } 2019\end{array}$ & $\begin{array}{l}\text { Greek Ministry of Education } \\
\text { and Religious Affairs }\end{array}$ \\
\hline & Population, 2011 & Hellenic Statistical Authority \\
\hline
\end{tabular}


Table 1. Cont.

\begin{tabular}{|c|c|c|}
\hline Indicators & Dataset, Year & Source \\
\hline \multirow{3}{*}{$\begin{array}{l}\text { Proximiy to sport } \\
\text { facilities }\end{array}$} & $\begin{array}{l}\text { Spatial layer (polygon) of sports } \\
\text { facilities, } 2012\end{array}$ & $\begin{array}{l}\text { Urban Atlas-European } \\
\text { Environment Agency }\end{array}$ \\
\hline & $\begin{array}{l}\text { Spatial layer (polyline) of road network, } \\
2020\end{array}$ & OpenStreetMap.org \\
\hline & $\begin{array}{l}\text { Spatial layer (polygon) of } \\
\text { municipalities, } 2011\end{array}$ & Hellenic Statistical Authority \\
\hline \multirow{2}{*}{$\begin{array}{l}\% \text { Population living } \\
\text { in houses without } \\
\text { basic facilities }\end{array}$} & $\begin{array}{l}\text { Population living in dwellings without } \\
\text { heating, WC, bathroom, kitchen, } 2011\end{array}$ & Hellenic Statistical Authority \\
\hline & $\begin{array}{l}\text { Total population (population living in } \\
\text { collective dwellings and non-classified } \\
\text { was excluded), } 2011\end{array}$ & Hellenic Statistical Authority \\
\hline Indicators & Dataset, Year & Source \\
\hline \multirow[b]{2}{*}{$\begin{array}{l}\% \text { Population living } \\
\text { in detached houses }\end{array}$} & $\begin{array}{l}\text { Population living in detached dwelling } \\
\text { units, } 2011\end{array}$ & Hellenic Statistical Authority \\
\hline & $\begin{array}{l}\text { Total population (population living in } \\
\text { collective dwellings and non-classified } \\
\text { was excluded), } 2011\end{array}$ & Hellenic Statistical Authority \\
\hline \multirow[b]{2}{*}{$\begin{array}{l}\% \text { Population living } \\
\text { in newly built units }\end{array}$} & $\begin{array}{l}\text { Population living in dwellings } \\
\text { constructed after 2005, } 2011\end{array}$ & Hellenic Statistical Authority \\
\hline & $\begin{array}{l}\text { Total population (population living in } \\
\text { irregular dwellings, collective } \\
\text { dwellings, and non-classified was } \\
\text { excluded), } 2011\end{array}$ & Hellenic Statistical Authority \\
\hline \multirow[b]{2}{*}{$\begin{array}{l}\text { Housing space }\left(\mathrm{m}^{2}\right) \\
\text { per person }\end{array}$} & Dwelling size per person, 2011 & Hellenic Statistical Authority \\
\hline & $\begin{array}{l}\text { Total population (population living in } \\
\text { collective dwellings and non-classified } \\
\text { was excluded), } 2011\end{array}$ & Hellenic Statistical Authority \\
\hline \multirow[t]{3}{*}{$\begin{array}{l}\text { Proximity to } \\
\text { recreational facilities }\end{array}$} & $\begin{array}{l}\text { Spatial layer (points) of theaters, } \\
\text { cinemas, cultural centers, recreational } \\
\text { parks, } 2020\end{array}$ & $\begin{array}{l}\text { Google Maps and other sites } \\
\text { of related infrastructures } \\
\text { (www.tripadvisor.gr, } \\
\text { www.vrisko.gr, www.xo.gr } \\
\text { (accessed on } 17 \text { May 2021)) }\end{array}$ \\
\hline & $\begin{array}{l}\text { Spatial layer (polyline) of road network, } \\
2020\end{array}$ & $\begin{array}{l}\text { OpenStreetMap.org (accessed } \\
\text { on } 17 \text { May 2021) }\end{array}$ \\
\hline & $\begin{array}{l}\text { Spatial layer (polygon) of } \\
\text { municipalities, } 2011\end{array}$ & Hellenic Statistical Authority \\
\hline \multirow[t]{3}{*}{$\begin{array}{l}\text { Proximity to cultural } \\
\text { facilities }\end{array}$} & $\begin{array}{l}\text { Spatial layer (points) of archeological } \\
\text { sites, museums and libraries, } 2020\end{array}$ & $\begin{array}{l}\text { Google Maps and other sites } \\
\text { of related infrastructures } \\
\text { (odysseus.culture.gr, } \\
\text { museumfinder.gr, } \\
\text { www.eebep.gr, } \\
\text { www.network.nlg.gr, www. } \\
\text { library4you.weebly.com, } \\
\text { www.visitgreece.gr, } \\
\text { www.vrisko.gr (accessed on } \\
17 \text { May 2021)) }\end{array}$ \\
\hline & $\begin{array}{l}\text { Spatial layer (polyline) of road network, } \\
2020\end{array}$ & $\begin{array}{l}\text { OpenStreetMap.org (accessed } \\
\text { on } 17 \text { May 2021) }\end{array}$ \\
\hline & $\begin{array}{l}\text { Spatial layer (polygon) of } \\
\text { municipalities, } 2011\end{array}$ & Hellenic Statistical Authority \\
\hline
\end{tabular}

\subsection{GIS Modeling}

GIS functionality was applied to estimate all indicators and composite criteria. Statistical data tables and spatial layers were stored in a geodatabase and GIS-supported 
procedures were implemented to geocode and aggregate all data in the corresponding municipality, as well as to produce secondary variables.

Tabular data were joined to spatial data, attributing to each municipality the corresponding statistics. To calculate percentages of land cover and density of roads, geometry area of polygons and length of linear entities were computed. Euclidean distance analysis was performed to calculate straight-line distances, while for the estimation of various accessibilities (such as time distances), GIS-based network analysis was implemented based on the on-road travel speed. Finally, zonal statistics tool was used to compute mean values for each municipality.

After the calculation of all indicators per municipality in the study area, their values were reclassified to a common ordinal scale with five categories from very low QoL level (value 1) to very high QoL level (value 5) [76,77].

Next, each composite criterion was calculated from its related variables by using the following formula:

$$
\mathrm{C}_{\mathrm{i}}=\frac{\sum_{\mathrm{i}}^{\mathrm{n}} \mathrm{V}_{\mathrm{i}}}{\mathrm{n}}
$$

where

$\mathrm{C}_{\mathrm{i}}=$ composite criterion

$\mathrm{n}=$ number of variables

$\mathrm{V}_{\mathrm{i}}=$ variable.

Finally, the overall QoL for each municipality was calculated from the composite criteria:

$$
\mathrm{QoL}=\frac{\sum_{\mathrm{i}}^{\mathrm{n}} \mathrm{C}_{\mathrm{i}}}{\mathrm{n}}
$$

where

QoL = overall urban quality of life

$\mathrm{n}=$ number of criteria

$\mathrm{C}_{\mathrm{i}}=$ composite criterion.

QoL values were categorized into three classes—high, moderate, and low QoL-using the quantile classification method. All criteria and overall QoL were mapped, and a series of thematic maps was created to illustrate spatial inequalities and zonation of QoL within AMA. Spatial analysis and mapping were performed using the ArcGIS version 10.2 (ESRI Inc., Redlands, CA, USA) software.

\section{Results}

As mentioned above, the QoL of the study area was assessed after the deployment of a composite index, with the integration of six criteria. Each criterion referred to a domain of QoL and was estimated by a set of indicators. The next figure (Figure 3) presents the spatial distribution of "Built environment", "Socioeconomic environment", and "Housing conditions" indicators.

Highly populated areas and lack of open spaces are typical for the central part of AMA (Municipalities of Athens, Kallithea, Nea Smyrni, Peristeri, etc.). Regarding the socioeconomic conditions, the unemployment rate is quite high (over 18\%) in the western part of AMA, while the percentage of higher educated people and the mean income in this area are quite low. Concerning the housing conditions, the municipalities with population who lives in houses without basic facilities are within the western part of AMA. A low percentage of the population lives in detached houses in the central and eastern part of AMA (Municipalities of Athens, Kallithea, Palaio Faliro, Nea Smyrni, Galatsi, Zografou, Kaisariani, and Vyronas), while the population who lives in new buildings is mostly within the northern part of AMA. Regarding the "space per person" indicator, most people in the western municipalities of AMA have less than $30 \mathrm{~m}^{2}$. 


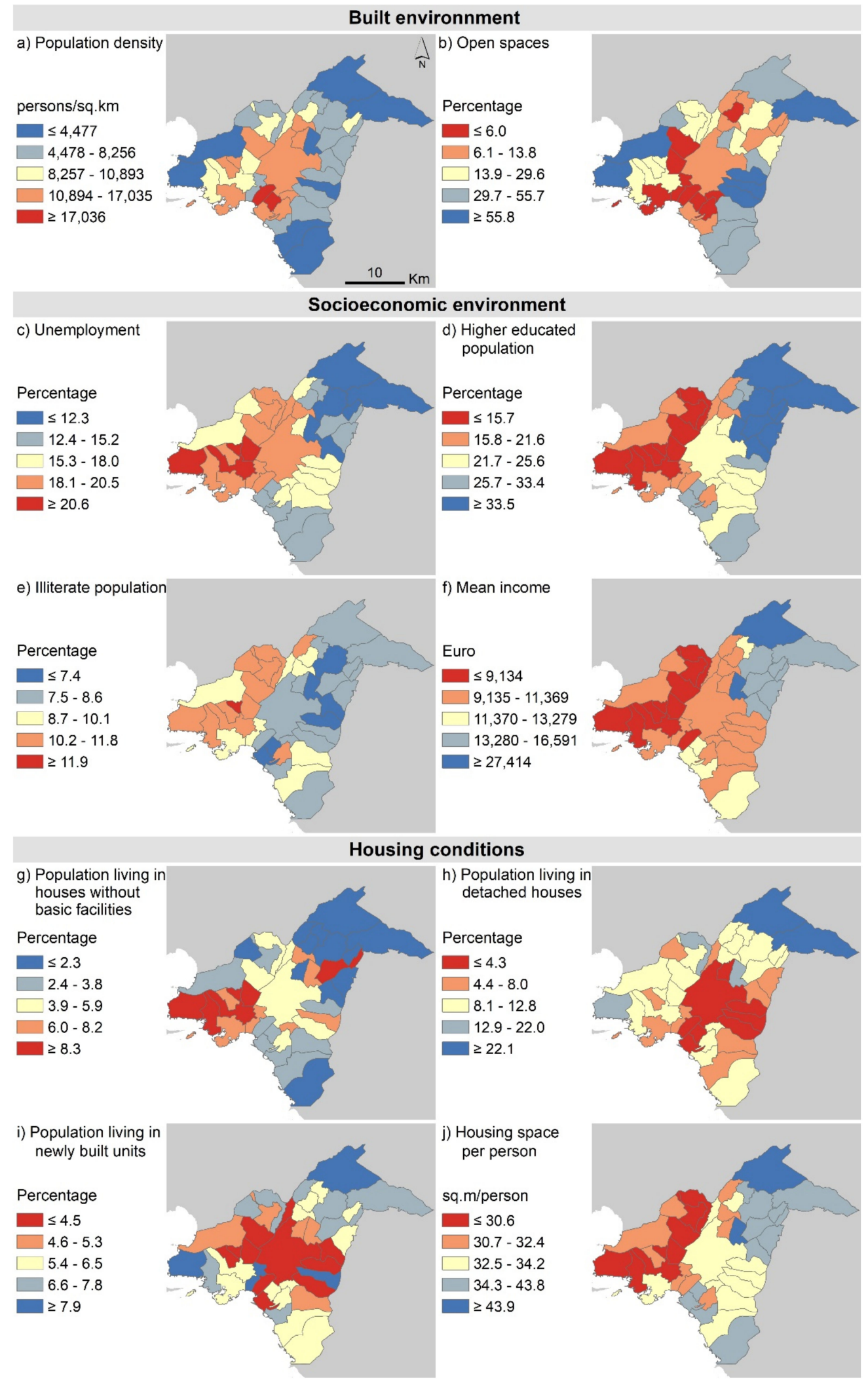

Figure 3. Indicators for the Built environment, Socioeconomic environment, and Housing conditions, across municipalities of AMA, Greece. (a) Population density, (b) open spaces, (c) unemployment, (d) high-educated population, (e) illiterate population, (f) income, (g) houses without basic facilities, (h) detached houses, (i) new buildings, (j) size of houses. (Red color in each map indicates low QoL and blue color high QoL values). 
The next figure (Figure 4) presents the spatial distribution of indicators for the Natural environment, Public sectors and infrastructures, and Cultural and recreation facilities.

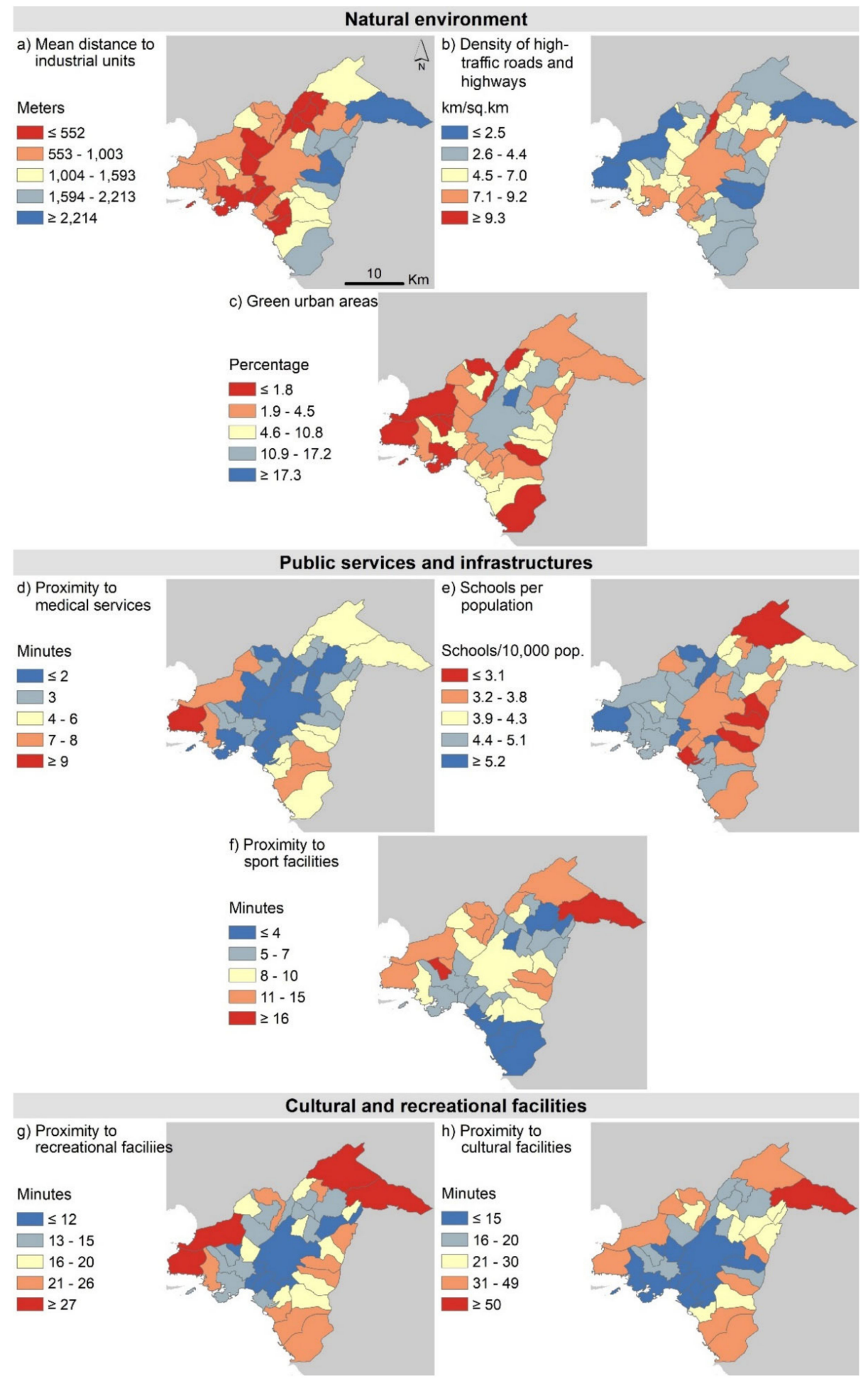

Figure 4. Indicators for the Natural environment, Public services and infrastructures, and Cultural and recreational facilities, across municipalities of AMA, Greece. (a) Mean distance to industrial units, (b) density of high-traffic roads and highways, (c) percentage of green urban areas, (d) proximity to medical services, (e) schools per 10,000 population, (f) proximity to sport facilities, (g) proximity recreational facilities, (h) proximity to cultural facilities. (Red color in each map indicates low QoL and blue color high QoL values). 
From this map, it becomes clear that the environment is more degraded in the western sector of Attica as it is close to industries and has no significant urban green. The central sector (Municipalities of Athens, Galatsi, Filothei-Psichiko, and Marousi) is also quite degraded (with the exception of the presence of urban green), as it has a high density of highways. The residents of the municipalities of the northern sector seem to experience the best environmental conditions. Figure 3 also presents that most of the medical services are located in the central AMA, and therefore, the time distance to access them is high for the municipalities in the borders of AMA. Meanwhile, in the western AMA, there are located the most schools per 100,000 inhabitants. The proximity to sports facilities is generally high in the southern part of AMA and in some pockets in the northern part (Municipalities of Galatsi, Marousi, and Vrilisia). In addition, the time distance to cultural and recreational facilities is very low within the central part of Athens as most of the museums and the archaeological sites are located in the Municipality of Athens. The spatial distribution of each composite criterion is shown in Figure 5.

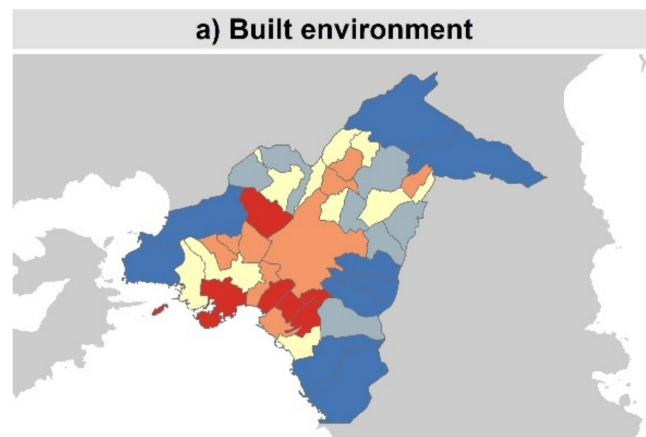

c) Socioeconomic environment

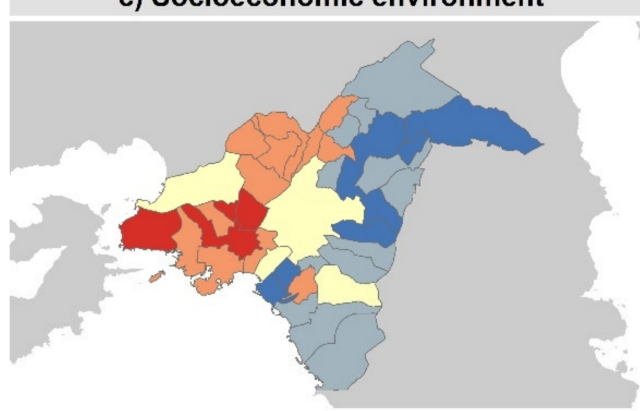

e) Housing conditions

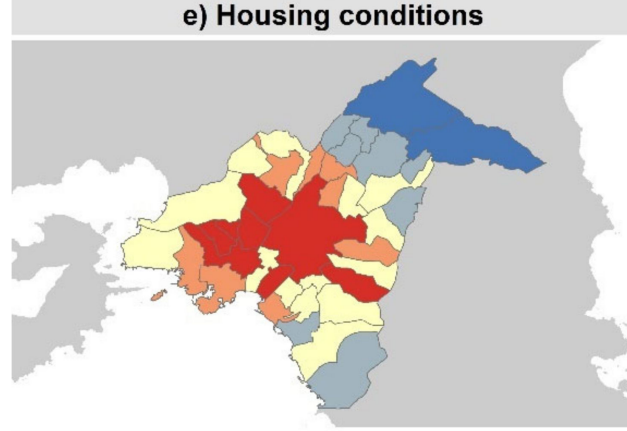

QoL

1-Very Low 2 - Low 3 -Moderate $\quad 4$ - High $\quad 5$ - Very High b) Natural environment

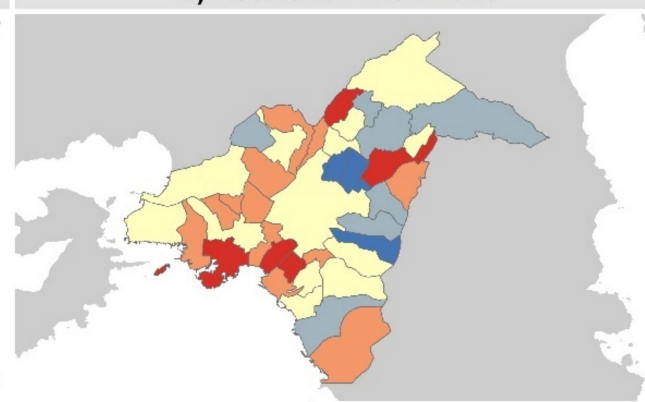

d) Public services and infrastructures

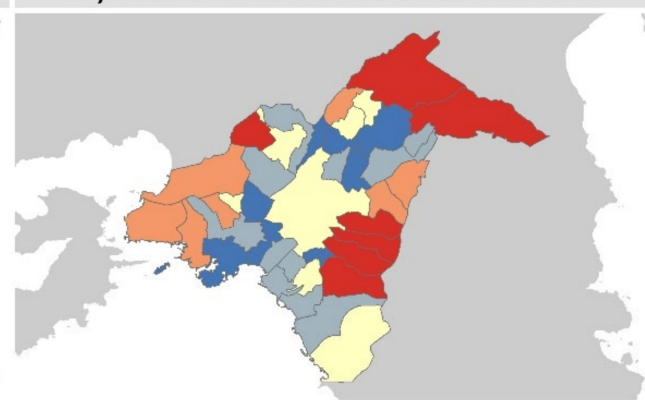

f) Cultural and recreational facilities

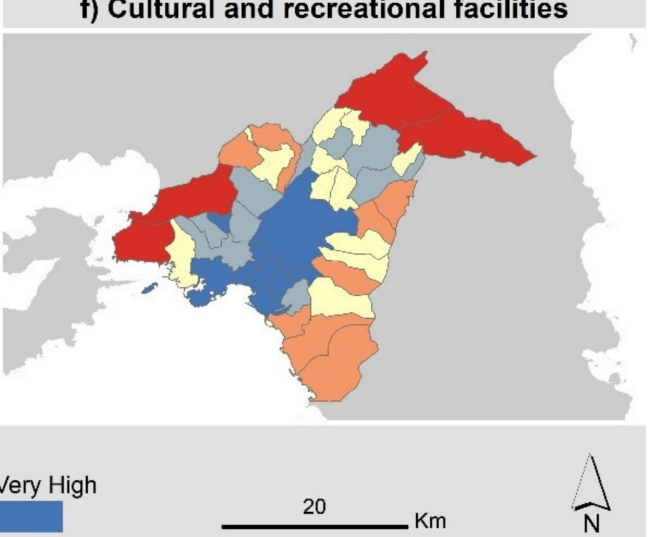

Figure 5. The composite criteria of QoL in AMA, Greece. (a) Built environment, (b) natural environment, (c) socioeconomic environment, (d) public services and infrastructures, (e) housing conditions, (f) cultural and recreational facilities.

The quality of the built environment is rather high in the perimeter of AMA and low in the center. For the natural environment, the spatial patterns are not so clear, although 
the west sector seems to be relatively degraded. For the socioeconomic environment, the picture is clearer: the northern and the southern part of AMA have high/very high values of QoL. On the contrary, the western part has rather low values.

Public services and infrastructures as mentioned above are located in the central AMA; thus, these areas have high values of QoL and the perimeter of AMA has the lowest values. Regarding the housing conditions, around the AMA center, the values are very low and are increasing toward its perimeter and, finally, exactly the reverse phenomenon occurs in terms of cultural and recreational facilities, i.e., low values are located at the perimeter and the highest are around the center of AMA.

Finally, the spatial distribution of the overall QoL is presented in Figure 6. This map revealed a zone with high QoL values in the northeastern and southeastern parts of the study area, and a zone with low QoL values in western AMA, whereas the central municipality (Municipality of Athens) is in an average situation.

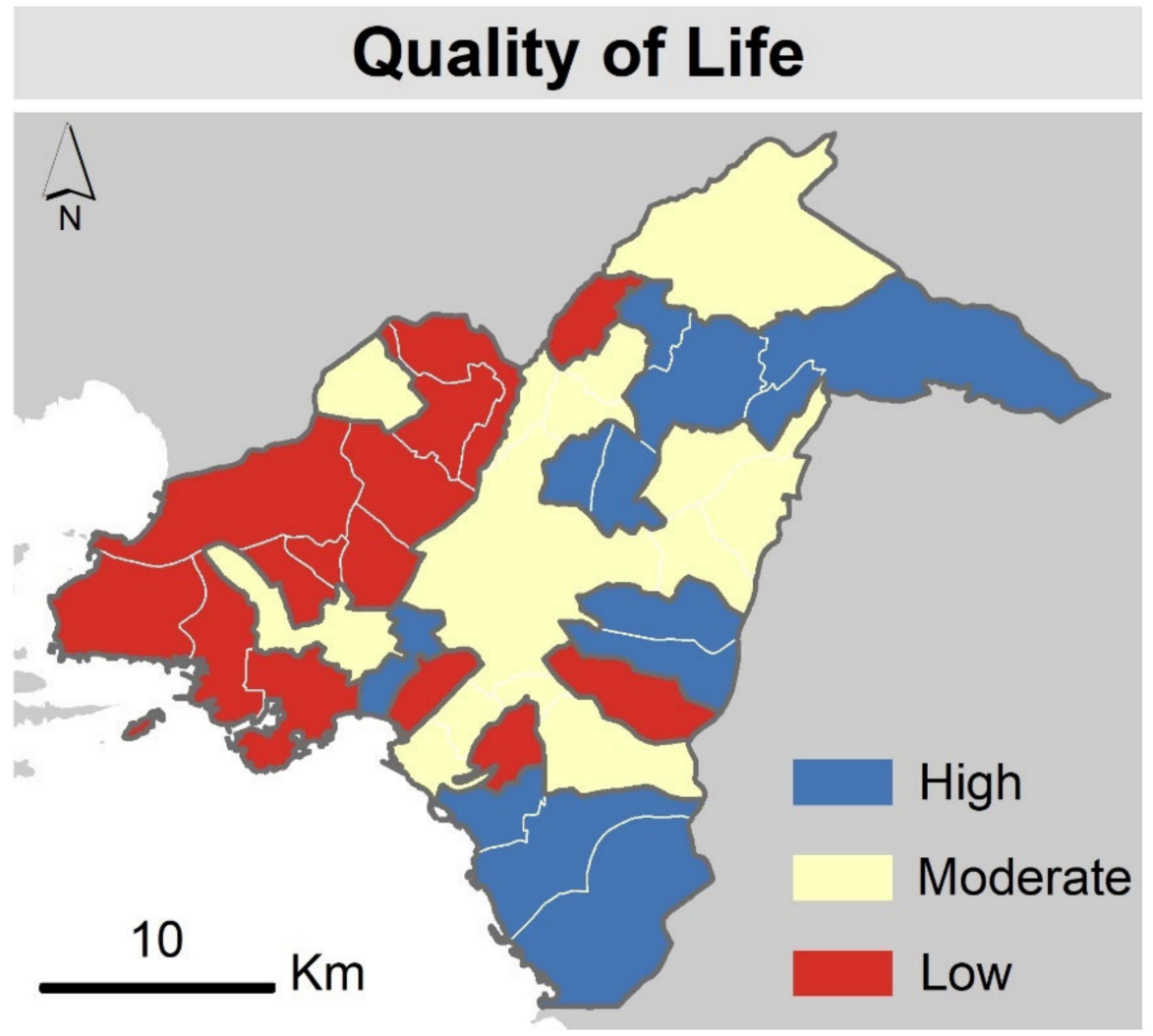

Figure 6. The final QoL map for AMA, Greece.

In Figures 7 and 8, satellite images of some of the most disadvantageous and advantageous municipalities demonstrate the spatial background where QoL is developing. Municipalities in disadvantaged areas B, C, and D (Figure 7) are characterized by more densely structured space as well as by lack of green urban areas and open spaces. Furthermore, they are crossed by large and high-traffic roads, contributing to high levels of noise and air pollution. Even though large areas of open and green spaces are identified at municipalities in area A (Figure 7), the main port of the country is localized at the coastal zone, concentrating also many industrial units and especially oil industries that lead to significant degradation of the natural environment. On the other hand, the advantageous municipalities (Figure 8) are less densely structured with several pockets of green urban areas and open spaces throughout the municipalities area. 

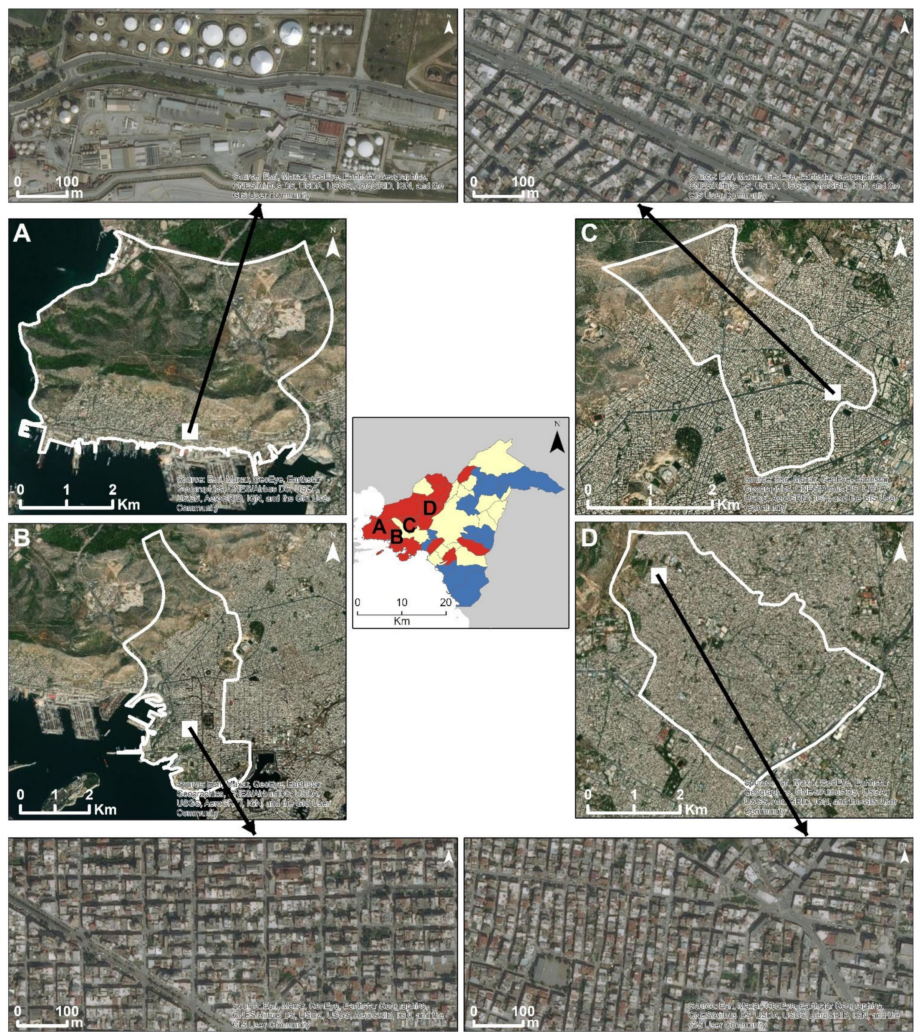

Figure 7. The urban background of disadvantageous municipalities. (A) Perama municipality, (B) Keratsini-Drapetsona municipality, (C) Korydallos municipality, (D) Peristeri municipality.
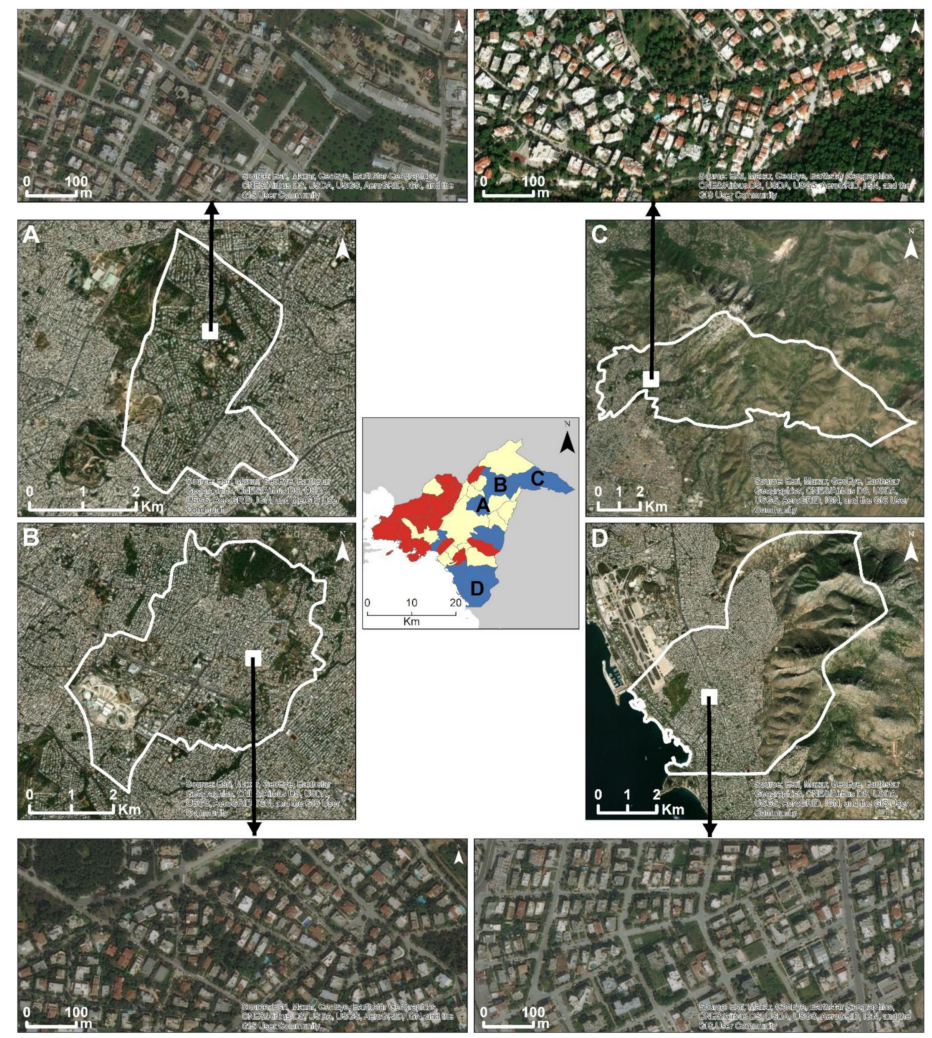

Figure 8. The urban background of advantageous municipalities. (A) Filothei-Psichiko municipality, (B) Aghia Paraskevi municipality, (C) Penteli municipality, (D) Glyfada municipality. 


\section{Discussion}

The aim of this study was to assess the QoL at the regional scale on the Athens Metropolitan Area, Greece. By applying a multicriteria analysis implemented in a GIS environment, the spatial distribution of QoL is shown on the final output. Overall, QoL indicates what is known in the circle of social geographers for AMA. There is a clear social division in Attica characterized by an axis that starts from the northeast and ends in the west and southwest. On one side of this axis, the northern, eastern, and southern regions present mainly very high values in terms of QoL, while respectively, the western part of Attica presents very small values. These different zones reflect the socioeconomic inequalities in the area under investigation [78], as lower and higher socioeconomic strata are concentrated in the western and north-southeast AMA sectors, respectively.

This geographical division is also evident regarding the housing conditions. Insufficient housing facilities and space are associated with the living conditions of underprivileged people that do not enjoy extended amenities, leading to poorer QoL [11,16,67].

On the contrary, the north and southeastern zones seem to have fewer public services and infrastructures, with poor access to medical services and sports facilities $[23,69]$. Those most distant from the center municipalities are also characterized by lower levels of QoL regarding the cultural and recreational facilities, whereas the central AMA seems to benefit due to the concentration of theaters, libraries, museums, and archaeological sites in the Athens municipality $[23,63,69,75]$. However, the center of AMA is characterized by poor natural and built environment and addresses the negative effects of air and noise pollution due to high population density, limited open spaces, high density of high-traffic roads, and proximity to industrial units.

These spatial inequalities within AMA, which have been explicitly analyzed by social geographers and urban planners $[79,80]$, allow the construction of a more theoretically grounded context for explaining QoL. The urban development model of AMA was based on simultaneous expansion and intensification [81]. It was part of the Greek post-war model of economic accumulation in which a comprehensive long-term development strategy was not outlined. The consequence of this situation was the prevalence of short-term economic growth criteria, which in turn undermined socially rational and at the same time sustainable urban development [82].

For QoL upgrade in the study area, the decision-makers could take advantage of the findings to develop targeted actions and plans based on the domains in which each area lags. Priority in macroeconomic and social policies should be given to the underprivileged municipalities of the western sector, especially in Nikaia-Aghios Ioannis Rentis, Egaleo, Aghia Varvara, and Perama. Interventions at the level of urban planning could upgrade the built and the natural environment of Nea Smyrni, Kallithea, and Piraeus municipalities, which scored very low levels at these criteria. Most municipalities at the borders of AMA seem to lack proximity to both public services and facilities as well as cultural and recreational facilities, leading to the need for the enhancement of such infrastructures in these areas. Regarding the housing conditions, eight municipalities (Peristeri, Athens, Vyronas, Kallithea, Nikaia-Aghios Ioannis Rentis, Egaleo, Aghia Varvara, Korydallos) appear to have insufficient housing space and/or housing buildings of low quality in terms of facilities and newly built units. In such areas, financial resources and motivations could be provided for housing improvement programs either for repairing or renovating buildings.

This study incorporates a series of strengths related to the design and the implementation of the proposed methodology. Initially, the variables selected to evaluate QoL criteria are either available or can easily create within GIS environment. Where data at this geographical level are limited, the construction of variables through a GIS-based modeling is a valuable option for the implementation of the proposed methodology. This methodology can be reproduced in urban areas where the same data may not be available or statistical variables are limited. Furthermore, the proposed spatial multicriteria analysis can be used-after the proper adaptations-in other urban areas, as it uses generally available datasets and standard GIS functionality. 
The GIS-based multicriteria analysis of QoL enables the mapping indicators and criteria $[17,83,84]$. These maps demonstrate the spatial distribution of each criterion and allow identifying spatial patterns of low or high QoL values [7]. As a result, QoL mapping is a powerful tool for stakeholders and local authorities to design general objectives and strategies, focusing on disadvantaged areas and eventually supporting the overall decisionmaking process. To the best of our knowledge, this is the first attempt to evaluate and investigate spatial inequalities of the QoL for AMA.

Finally, we should point out some limitations and assumptions of the proposed method for the assessment and mapping of QoL. First of all, the proposed model is designed for the regional to local scale. At large scales, more exhaustive datasets and detailed information are required. Green areas are a prime example, as house yards in the suburbs are not listed as green urban areas. A second assumption is related to the selection of the criteria. The selection for this analysis was based on the findings from international literature as well as on the data availability. Furthermore, another limitation of this study is that the developed multicriteria analysis does not take into account the mutual relationships between the criteria. Finally, it should be mentioned that according to our analysis, the output map presents only the spatial distribution of QoL for AMA and not its temporal dimension. Thus, we assume that the output map demonstrates a snapshot of the QoL in Athens. Therefore, the result of this study should guide quantitative analysis at a detailed scale. Despite these limitations, the produced map could be very useful to community and local decision-makers for future land-use planning and the implementation of targeted interventions.

\section{Conclusions}

This study proposes a methodological framework for mapping QoL and presents the implementation of this framework in AMA. Different zones within the AMA seem to attribute various socioeconomic factors. Two clusters of advantageous municipalities in the northeastern and southeastern study areas, and a cluster of disadvantageous municipalities in western AMA, revealed significant inequalities among the educational and economic level of the residents, as well as among the size, the quality, and the amenities of the houses. The central municipalities of AMA benefit from proximity to public services and recreational facilities, although disadvantageous conditions in built and natural environment such as high population density, limited open spaces, and proximity to industrial units decrease the overall QoL. On the other hand, more distant municipalities from the center of AMA are less densely populated and contain more open spaces. Mapping QoL is a functional tool for local authorities to develop future strategies targeting the improvement of QoL. This study may be conducive to more effective decision making during the socioeconomic crisis by designing targeted local development programs and allocating effectively the limited financial resources. In future work, the methodology can be implemented over time periods to identify QoL trends, while mapping can be applied at a neighborhood level to identify spatial inequalities within municipalities.

Author Contributions: Conceptualization, Antigoni Faka, Kleomenis Kalogeropoulos, Thomas Maloutas and Christos Chalkias; Methodology, Antigoni Faka, Kleomenis Kalogeropoulos, Thomas Maloutas and Christos Chalkias; Analysis, Antigoni Faka and Kleomenis Kalogeropoulos; Writingoriginal draft preparation, Antigoni Faka, Kleomenis Kalogeropoulos, and Thomas Maloutas; Writing-review and editing, Antigoni Faka, Kleomenis Kalogeropoulos, Thomas Maloutas and Christos Chalkias; Visualization, Antigoni Faka, Christos Chalkias; Supervision, Christos Chalkias and Thomas Maloutas. All authors have read and agreed to the published version of the manuscript.

Funding: This research was funded by "Human Resources Development, Education and Lifelong Learning".

Data Availability Statement: No ethical approval was required due to use of publically available and/or aggregate secondary data.

Conflicts of Interest: The authors declare no conflict of interest. 


\section{References}

1. Schalock, R.L. Three Decades of Quality of Life. Focus Autism Other Dev. Disabil. 2000, 15, 116-127. [CrossRef]

2. Farquhar, M. Definitions of quality of life: A taxonomy. J. Adv. Nurs. 1995, 22, 502-508. [CrossRef]

3. Maggino, F.; Zumbo, B.D. Measuring the Quality of Life and the Construction of Social Indicators. In Handbook of Social Indicators and Quality of Life Research; Land, K.C., Michalos, A.C., Sirgy, M.J., Eds.; Springer: Berlin, Germany, 2012; pp. $201-238$.

4. Sirgy, M.J.; Michalos, A.C.; Ferriss, A.L.; Easterlin, R.A.; Patrick, D.; Pavot, W. The quality-of-life (QOL) research movement: Past, present, and future. Soc. Indic. Res. 2006, 76, 343-466. [CrossRef]

5. Gill, T.M. A Critical Appraisal of the Quality of Quality-of-Life Measurements. JAMA J. Am. Med. Assoc. 1994, 272, 619. [CrossRef]

6. WHOQOL. User Manual. In Division of Mental Health and Prevention of Substance Abuse; WHO: Geneva, Switzerland, 2012.

7. Faka, A. Assessing Quality of Life Inequalities. A Geographical Approach. ISPRS Int. J. Geo-Inf. 2020, 9, 600. [CrossRef]

8. Eurofound. Quality of Life in Europe-First European Quality of Life Survey; Publications Office of the European Union: Luxembourg, 2004.

9. Eurofound. Second European Quality of Life Survey-Overview; Publications Office of the European Union: Luxembourg, 2009.

10. Eurofound. Third European Quality of Life Survey-Quality of Life in Europe: Impacts of the Crisis; Publications Office of the European Union: Luxembourg, 2012.

11. Eurofound. European Quality of Life Survey 2016: Quality of Life, Quality of Public Services, and Quality of Society; Publications Office of the European Union: Luxembourg, 2017.

12. European Commission. Quality of Life in European Cities 2015; Office for Official Publications of the European Communities: Luxembourg, 2016.

13. EEA-European Environment Agency. Ensuring Quality of Life in Europe's Cities and Towns, EEA Report No 5/2009; Office for Official Publications of the European Communities: Luxembourg, 2009.

14. Murgaš, F.; Klobučník, M. Municipalities and regions as good places to live: Index of quality of life in the Czech Republic. Appl. Res. Qual. Life 2016, 11, 553-570. [CrossRef]

15. Najafpour, H.; Bigdeli Rad, V.; Lamit, H.B.; Rosley, M.S.F.B. The systematic review on quality of life in urban neighborhoods. Life Sci. J. 2014, 11, 355-364.

16. Linares, S.; Mikkelsen, C.A.; Velázquez, G.A.; Celemín, J.P. Spatial Segregation and Quality of Life: Empirical Analysis of Medium-Sized Cities of Buenos Aires Province. In Indicators of Quality of Life in Latin America; Tonon, G., Ed.; Springer: Berlin, Germany, 2016; Volume 62, pp. 201-218.

17. Martinez, J. Mapping dynamic indicators of quality of life: A case in Rosario, Argentina. Appl. Res. Qual. Life 2019, 14, 777-798. [CrossRef]

18. McCann, E.J. “Best places”: Interurban competition, quality of life and popular media discourse. Urban Stud. 2004, 41, 1909-1929. [CrossRef]

19. Murgaš, F. Geographical conceptualization of quality of life. Ekol. Bratisl. 2016, 35, 309-319. [CrossRef]

20. McCrea, R.; Shyy, T.K.; Stimson, R. What is the Strength of the Link Between Objective and Subjective Indicators of Urban Quality of Life? Appl. Res. Qual. Life. 2006, 1, 79-96. [CrossRef]

21. Li, G.; Weng, Q. Measuring the quality of life in city of Indianapolis by integration of remote sensing and census data. Int. J. Remote Sens. 2007, 28, 249-267. [CrossRef]

22. Elmahdi, A.; Afify, A. Development of a GIS tool for qualitative assessment of the Egyptian's quality of life. Environmentalist 2007, 27, 183-194. [CrossRef]

23. Kazemzadeh-Zow, A.; Darvishi Boloorani, A.; Samany, N.N.; Toomanian, A.; Pourahmad, A. Spatiotemporal modelling of urban quality of life (UQoL) using satellite images and GIS. Int. J. Remote Sens. 2018, 39, 6095-6116. [CrossRef]

24. Gu, X.; Zhang, L.; Tao, S.; Xie, B. Spatial Accessibility to Healthcare Services in Metropolitan Suburbs: The Case of Qingpu, Shanghai. Int. J. Environ. Res. Public Health. 2019, 16, 225. [CrossRef]

25. Lu, C.; Jin, S.; Tang, X.; Lu, C.; Li, H.; Pang, J. Spatio-Temporal Comprehensive Measurements of Chinese Citizens' Health Levels and Associated Influencing Factors. Healthcare 2020, 8, 231. [CrossRef] [PubMed]

26. Merschdorf, H.; Hodgson, M.E.; Blaschke, T. Modeling Quality of Urban Life Using a Geospatial Approach. Urban Sci. 2020, 4, 5. [CrossRef]

27. Bartoněk, D.; Bureš, J.; Švábenský, O. Evaluation of Influence of the Environment on the Choice of Buildings for Residential Living. Sustainability 2020, 12, 4901. [CrossRef]

28. Zhong, T.; Lü, G.; Zhong, X.; Tang, H.; Ye, Y. Measuring Human-Scale Living Convenience through Multi-Sourced Urban Data and a Geodesign Approach: Buildings as Analytical Units. Sustainability 2020, 12, 4712. [CrossRef]

29. Giuffrida, N.; Le Pira, M.; Inturri, G.; Ignaccolo, M. Mapping with Stakeholders: An Overview of Public Participatory GIS and VGI in Transport Decision-Making. ISPRS Int. J. Geo-Inf. 2019, 8, 198. [CrossRef]

30. Abd El Karim, A.; Awawdeh, M.M. Integrating GIS Accessibility and Location-Allocation Models with Multicriteria Decision Analysis for Evaluating Quality of Life in Buraidah City, KSA. Sustainability 2020, 12, 1412. [CrossRef]

31. Vukmirovic, M.; Gavrilovic, S.; Stojanovic, D. The Improvement of the Comfort of Public Spaces as a Local Initiative in Coping with Climate Change. Sustainability 2019, 11, 6546. [CrossRef]

32. Martínez, J. The use of GIS and indicators to monitor intra-urban inequalities. A case study in Rosario, Argentina. Habitat Int. 2009, 33, 387-396. [CrossRef] 
33. OECD. How's Life? 2017: Measuring Well-Being; OECD Publishing: Paris, France, 2017.

34. UN-Habitat. Measurement of City Prosperity: Methodology and Metadata; United Nations Human Settlements Programme: Nairobi, Kenya, 2016.

35. Eurostat. Quality of Life Indicators. 2020. Available online: https://ec.europa.eu/eurostat/statistics-explained/index.php?title= Quality_of_life_indicators_-_measuring_quality_of_life (accessed on 23 December 2020).

36. Pacione, M. Urban Environmental Quality and Human Well-Being-A Social Geographical Perspective. Landsc. Urban Plan. 2003, 65, 19-30. [CrossRef]

37. Schmitt, R.B.; Noll, H. Conceptual Framework and Structure of a European System of Social Indicators, EU Reporting Paper No 9; Centre for Survey Re-Search and Methodology (ZUMA)—Social Indicators Department: Mannheim, Germany, 2000.

38. Hagerty, M.R.; Land, K.C. Constructing Summary Indices of Quality of Life: A Model for the Effect of Heterogeneous Importance Weights. Sociol. Methods Res. 2007, 35, 455-496. [CrossRef]

39. Eurofound. Monitoring Quality of Life in Europe; Publications Office of the European Union: Luxembourg, 2003.

40. Van Kamp, I.; Leidelmeijer, K.; Marsman, G. Urban environmental quality and human well-being: Towards a conceptual framework and demarcation of concepts; a literature study. Landsc. Urban. Plan. 2003, 65, 5-18. [CrossRef]

41. Biagi, B.; Ladu, M.G.; Meleddu, M. Urban Quality of Life and Capabilities: An Experimental Study. Ecol. Econ. 2018, 150, 137-152. [CrossRef]

42. Cabello Eras, J.J.; Covas Varela, D.; Hernández Pérez, G.D.; Sagastume Gutiérrez, A.; García Lorenzo, D.; Vandecasteele, C.; Hens, L. Comparative study of the urban quality of life in Cuban first-level cities from an objective dimension. Environ. Dev. Sustain. 2014, 16, 195-215. [CrossRef]

43. Das, D. Urban quality of life: A case study of Guwahati. Soc. Indic. Res. 2008, 88, 297-310. [CrossRef]

44. Feneri, A.M.; Vagiona, D.; Karanikolas, N. Measuring Quality of Life (QoL) in Urban Environment: An Integrated Approach. In Proceedings of the 13th International Conference on Environmental Science and Technology, Athens, Greece, 5-7 September 2013.

45. Garau, C.; Pavan, V.M. Evaluating Urban Quality: Indicators and Assessment Tools for Smart Sustainable Cities. Sustainability 2018, 10, 575. [CrossRef]

46. Peach, N.D.; Petach, L.A. Development and Quality of Life in Cities. Econ. Dev. Q. 2016, 30, 32-45. [CrossRef]

47. Psatha, E.; Deffner, A.; Psycharis, Y. Defining the Quality of Urban Life: Which Factors Should Be Considered? In Proceedings of the 51st Congress of the European Regional Science Association: New Challenges for European Regions and Urban Areas in a Globalised World, Barcelona, Spain, 30 August 2011-3 September 2011.

48. Blomquist, G.C. Measuring Quality of Life. In A Companion to Urban Economics; Arnott, R.J., McMillen, D.P., Eds.; Blackwell Publishing: Oxford, UK, 2006; pp. 479-482.

49. Santos, L.D.; Martins, I. Monitoring urban quality of life: The porto experience. Soc. Indic. Res. 2007, 80, 411-425. [CrossRef]

50. Serag El Din, H.; Shalaby, A.; Farouh, H.E.; Elariane, S.A. Principles of urban quality of life for a neighborhood. HBRC J. 2013, 9 , 86-92. [CrossRef]

51. Longley, P.A.; Goodchild, M.F.; Maguire, D.J.; Rhind, D.W. Geographic Information Systems and Science, 2nd ed.; John Wiley and Sons: Chichester, UK, 2005.

52. Zunino, A.; Velázquez, G.; Celemín, J.P.; Mateos, C.; Hirsch, M.; Rodriguez, J.M. Evaluating the Performance of Three Popular Web Mapping Libraries: A Case Study Using Argentina's Life Quality Index. ISPRS Int. J. Geo-Inf. 2020, 9, 563. [CrossRef]

53. Feneri, A.M.; Vagiona, D.; Karanikolas, N. Multi-criteria decision making to measure quality of life: An Integrated approach for implementation in the urban area of Thessaloniki, Greece. Appl. Res. Qual. Life 2015, 10, 573-587. [CrossRef]

54. Ivaldi, E.; Bonatti, G.; Soliani, R. Composite index for quality of life in Italian cities: An application to URBES indicators. Rev. Econ. Financ. 2014, 4, 18-32.

55. Mizgajski, A.; Walaszek, M.; Kaczmarek, T. Determinants of the quality of life in the communes of the poznań agglomeration: A quantitative approach. Quaest. Geogr. 2014, 33, 67-80. [CrossRef]

56. Eurostat-Spatial Units. Available online: https://ec.europa.eu/eurostat/web/cities/spatial-units (accessed on 25 April 2021).

57. Kandylis, G.; Maloutas, T.; Sayas, J. Immigration, inequality and diversity: Socio-ethnic hierarchy and spatial organization in Athens, Greece. Eur. Urban Reg. Stud. 2012, 19, 67-286. [CrossRef]

58. Pukeliene, V.; Starkauskiene, V. Quality of life: Factors determining its measurement complexity. Eng. Econ. 2011, 22, 147-156. [CrossRef]

59. Başkan, A.H.; Zorba, E.; Bayrakdar, A. Impact of the population density on quality of life. J. Hum. Sci. 2017, 14, 506-518. [CrossRef]

60. Winters, J.V.; Li, Y. Urbanisation, natural amenities and subjective well-being: Evidence from US counties. Urban Stud. 2017, 54, 1956-1973. [CrossRef]

61. Cramer, V.; Torgersen, S.; Kringlen, E. Quality of life in a city: The effect of population density. Soc. Indic. Res. 2004, 69, 103-116. [CrossRef]

62. Science for Environment Policy. What Are the Health Costs of Environmental Pollution? Future Brief 21. Brief Produced for the European Commission DG Environment by the Science Communication Unit; UWE: Bristol, UK, 2018. Available online: http:/ / ec.europa.eu/science-environment-policy (accessed on 17 December 2020). 
63. Eurofound. Third European Quality of Life Survey-Quality of Life in Europe: Social Inequalities; Publications Office of the European Union: Luxembourg, 2013. Available online: https://www.eurofound.europa.eu/sites/default/files/ef_publication/field_ef_ document/ef1362en.pdf (accessed on 17 December 2020).

64. OECD. How's Life? 2013: Measuring Well-Being; OECD Publishing: Paris, France, 2013. Available online: http://www.oecd.org/ sdd/3013071e.pdf (accessed on 17 December 2020).

65. Rose, R.; Munro, N.; Wallace, C. Second European Quality of Life Survey: Quality of Life in Europe 2003-2007; European Foundation for the Improvement of Living and Working Conditions: Dublin, Ireland, 2009.

66. UNESCO Institute for Statistics. International Standard Classification of Education ISCED 2011; UNESCO Institute for Statistics: Montréal, QC, Canada, 2012. Available online: http://uis.unesco.org/sites/default/files/documents/international-standardclassification-of-education-isced-2011-en.pdf (accessed on 17 December 2020).

67. Sirgy, M.J.; Cornwell, T. How neighborhood features affect quality of life. Soc. Indic. Res. 2002, 59, 79-114. [CrossRef]

68. Witten, K.; Exeter, D.; Field, A. The quality of urban environments: Mapping variation in access to community resources. Urban Stud. 2003, 40, 161-177. [CrossRef]

69. Weziak-Białowolska, D. Quality of life in cities-Empirical evidence in comparative European perspective. Cities 2016, 58, 87-96. [CrossRef]

70. Apparicio, P.; Séguin, A.M.; Naud, D. The quality of the urban environment around public housing buildings in Montréal: An objective approach based on GIS and multivariate statistical analysis. Soc. Indic. Res. 2008, 86, 355-380. [CrossRef]

71. Terzi, F.; Türkoğlu, H.D.; Bölen, F.; Baran, P.K.; Salihoğlu, T. Residents' Perception of Cultural Activities as Quality of Life in Istanbul. Soc. Indic. Res. 2015, 122, 211-234. [CrossRef]

72. Marans, R.W.; Kweon, B. The quality of life in metro Detroit at the beginning of the millennium. In Investigating Quality of Urban Life; Marans, R.W., Stimson, R., Eds.; Springer: New York, NY, USA, 2011.

73. Beggs, B.A.; Elkins, D.J.; The influence of leisure motivation on leisure satisfaction. LARNet; The Cyber Journal of Applied Leisure and Recreation Research. 2010. Available online: http:/ /larnet.org/2010-02.html (accessed on 23 December 2020).

74. Oldenburg, R. The Great Good Place; Marlowe \& Co.: New York, NY, USA, 1997.

75. Lloyd, K.M.; Auld, C.J. The role of leisure in determining quality of life: Issues of content and measurement. Soc. Indic. Res. 2002, 57, 43-71. [CrossRef]

76. Jenks, G.F. Optimal Data Classification for Choropleth Maps. In University of Kansas Occasional Paper; University of Kansas: Lawrence, KS, USA, 1977.

77. Dent, B. Cartography, Thematic Map Design, 5th ed.; McGraw Hill: Boston, MA, USA, 1999.

78. Chalkias, C.; Papadopoulos, A.G.; Kalogeropoulos, K.; Tambalis, K.; Psarra, G.; Sidossis, L. Geographical heterogeneity of the relationship between childhood obesi-ty and socio-environmental status: Empirical evidence from Athens, Greece. Appl. Geogr. 2013, 37, 34-43. [CrossRef]

79. Emmanuel, D. Socio-economic inequalities and housing in Athens: Impacts of the monetary revolution of the 1990s. Greek Rev. Soc. Res. 2004, 113, 121-144. [CrossRef]

80. Maloutas, T. Segregation and residential mobility. Spatially entrapped socialmobility and its impact on segregation in Athens. Eur. Urban Reg. Stud. 2004, 11, 195-211. [CrossRef]

81. Arapoglou, V.; Karadimitriou, N.; Maloutas, T.; Sayas, J. Multiple deprivation in Athens: A legacy of persisting and deepening spatial divisions. In Hellenic Observatory Discussion Papers on Greece and Southeast Europe (157); Hellenic Observatory; European Institute; LSE: London, UK, 2021.

82. Karadimitriou, N.; Maloutas, T.; Arapoglou, V.P. Multiple Deprivation and Urban Development in Athens, Greece: Spatial Trends and the Role of Access to Housing. Land 2021, 10, 290. [CrossRef]

83. Ram Mohan Rao, K.; Kant, Y.; Gahlaut, N.; Roy, P.S. Assessment of quality of life in Uttarakhand, India using geospatial techniques. Geocarto Int. 2012, 27, 315-328.

84. Shyy, T.K.; Stimson, R.; Chhetri, P.; Western, J. Mapping quality of life in the south east Queensland region with a web-based application. J. Spat. Sci. 2007, 52, 13-22. [CrossRef] 